\title{
Cellular and Molecular Adaptation of Bovine Granulosa Cells and Oocytes under Heat Stress
}

\author{
Adnan Khan $\left.{ }^{1,+}{ }^{(}\right)$, Muhammad Zahoor Khan ${ }^{1,+}$, Saqib Umer ${ }^{2}{ }^{(D}$, Ibrar Muhammad Khan ${ }^{3}{ }^{(D)}$, \\ Huitao $\mathrm{Xu}^{2}$, Huabin $\mathrm{Zhu}{ }^{2}$ and Yachun Wang ${ }^{1, * \mathbb{D}}$ \\ 1 Key Laboratory of Animal Genetics, Breeding, and Reproduction, MARA; National Engineering Laboratory \\ for Animal Breeding, College of Animal Science and Technology, China Agricultural University, \\ Beijing 100193, China; dr.adnan93@cau.edu.cn (A.K.); zahoorkhattak91@yahoo.com (M.Z.K.) \\ 2 Embryo Biotechnology and Reproduction Laboratory, Institute of Animal Sciences, Chinese Academy of \\ Agricultural Sciences, Beijing 100193, China; Saqibumar33@hotmail.com (S.U.); xuhuitao104@163.com (H.X.); \\ Zhuhuabin@caas.cn (H.Z.) \\ 3 Anhui Provincial Laboratory of Local Livestock and Poultry Genetical Resources Conservation and \\ Breeding, College of Animal Science and Technology, Anhui Agricultural University, Hefei 230036, China; \\ Ibrar.pesh@gmail.com \\ * Correspondence: wangyachun@cau.edu.cn; Tel.: +86-10-627-324-611 \\ + These authors contributed equally to this work.
}

Received: 26 November 2019; Accepted: 8 January 2020; Published: 9 January 2020

check for updates

Simple Summary: Heat stress can have large effects on most aspects of reproductive function in dairy cows. A hot environment can increase blood, rectal, and uterine temperatures, alter ovarian folliculogenesis, suppress fertility, oogenesis, and embryogenesis and ultimately reduce conception and pregnancy rates. Among the components of the female reproductive tract, the ovarian pool of follicles and their enclosed granulosa cells and oocytes are highly sensitive to hyperthermia. Many effects of elevated temperature on granulosa cells and developing oocytes involve increased production of reactive oxygen species, subsequently induce cellular apoptosis, and decrease the developmental ability of oocytes to be fertilized. Furthermore, heat stress-associated reproductive disorders are associated with altered progesterone and reduced estradiol production by ovarian follicles. The review mainly focuses on the follicle-enclosed granulosa cells and oocytes, provides new insights into the cellular and molecular adaptations of granulosa cells and oocyte under heat stress, depicts the role of the follicle microenvironment, and discusses some mechanisms that might underlie oocyte impairment. This study provides a possible way for the genetic adaptation to heat stress both for the regulation of body temperature and cellular resistance to elevated temperature.

\begin{abstract}
Heat stress has long been recognized as a challenging issue that severely influences the reproductive functions of dairy cattle, disrupting oocyte development during fetal growth. These detrimental effects of heat stress are the result of either the hyperthermia associated with heat stress or the physiological adjustments made by the heat-stressed animal to regulate body temperature. In addition, elevated temperatures have been implicated in increasing the production of reactive oxygen species. Thus, understanding the impact of heat stress on reproductive functions, from a cellular to molecular level, might help in selecting heat-resilient dairy cattle and developing heat stress mitigation strategies. In the present paper, we have attempted to describe the changes in the reproductive system and function of dairy cattle in response to heat stress by reviewing the latest literature in this area. The review provides useful knowledge on the cellular and genetic basis of oocyte and granulosa cells in heat-stressed dairy cattle, which could be helpful for future research in this area.
\end{abstract}

Keywords: heat stress; dairy cattle; granulosa cell; oocyte; cellular and molecular level 


\section{Introduction}

Heat stress induces infertility in dairy cows and represents a major source of economic loss to the livestock sector [1-4]. Mammals typically function at high body temperatures ranging from 35 to $39^{\circ} \mathrm{C}$, while the increase in body temperatures to levels higher than the surrounding environment is due to the high metabolic rate achieved by catabolism of energy resources. Body temperature is closely regulated by balancing heat production with heat loss to the environment via conduction, convection, radiation, and evaporation. The set point for body temperature regulation is not fixed, but may differ on a daily basis in some animals as part of the hibernation response or in response to changes in ambient temperature or other indications [5].

The mammalian ovarian follicle is composed of an oocyte enclosed by a layer of granulosa cells (GCs). During folliculogenesis, the oocyte experiences a chain of biological events (ovulation, fertilization, and embryo development) under the influence of signals and hormones produced by the hypothalamus-pituitary-gonadal (H-P-G) axis and the GCs [6-9]. Oocyte maturation and ovulation, proliferation, and differentiation of GCs is critical for normal follicular growth $[10,11]$, and high environmental temperatures and humidity compromise fertility [12].

Heat stress (HS) is one of the environmental factors which has detrimental effects on ovarian function [13] and consequently decreases the developmental competence of oocytes to be fertilized and their further development into competent embryos [14]. The homeokinetic changes that regulate body temperature due to HS can impair reproductive function. Fertility impairment is a costly consequence of HS in hot and humid climates $[15,16]$. In a fertility study, cows were inseminated during the winter with semen collected either during the cold or hot season, and a lower pregnancy rate was observed for the semen collected during the hot season, signifying that oocyte quality—rather than that of spermatozoa-is the main reason for fertilization failure during the hot season. A study has shown that HS increases polyspermy during in vitro fertilization and reduces the conception rate by disrupting the antipolyspermy system in oocytes [17], indicating that HS during fertilization mainly affects the oocyte and its developmental competence.

HS activates a dynamic gene expression system and adaptive biochemical responses [18]. These responses are a highly conserved cascade of protein activation and altered gene expression in response to a variety of stressors [19]. The gene expression component of this network is under heat shock transcription factor (HSF) regulation [20]. The central role that heat shock proteins (HSPs) have in cytoprotection during HS is demonstrated by the fact that HSP overexpression protects against hyperthermia, circulatory shock, and cerebral ischemia during heat stroke [21].

This review briefly discusses the impact of HS on ovarian function, focusing on its impairment of the follicle-enclosed cells, i.e., GCs and oocytes. New insights into heat-induced cellular and molecular alterations are presented. Two potential mechanisms (i.e., apoptosis and oxidative stress) by which HS disrupts ovarian cells (GCs) and oocytes are explored. Furthermore, the latest research findings and data on the impact of HS on GCs and oocytes are summarized. Due to the complexity of the problem and for the ease of readers, each section includes basic context and relevant knowledge related to the effects of HS in general, followed by specific impacts on ovarian physiology and oocyte function that are required for a clear understanding of dairy cattle reproduction.

\section{Heat Stress Assessment}

The relationship between ambient temperature and rectal temperature (RT) has been studied extensively. In Florida, temperatures of 29.7 and $31.4^{\circ} \mathrm{C}$ were correlated with an average RT of $39^{\circ} \mathrm{C}$ (mild hyperthermia) and $39.5^{\circ} \mathrm{C}$ (hyperthermia), respectively [22]. RTs greater than $39^{\circ} \mathrm{C}$ represent a degree of HS that affects milk production and fertility $[23,24]$. Relative humidity $(\mathrm{RH})$ also contributes to the intensity of HS in addition to the ambient temperature. Efforts were made to incorporate environmental factors into a single index, but the ratio of success was limited except for the temperature 
humidity index (THI) [25]. For instance, during the summer, we collected the data from many dairy farms in Beijing. THI was calculated based on the following formula [26]:

$$
\mathrm{THI}=(0.8 \times \mathrm{T})+[(\mathrm{RH} / 100) \times(\mathrm{T}-14.4)]+46.4,
$$

where T: dry bulb temperature $\left({ }^{\circ} \mathrm{C}\right)$; $\mathrm{RH}$ : relative humidity (\%). The results showed that high environmental temperature and humidity, combined as THI, could affect RT. We found that in summer, the body temperature may rise to $41^{\circ} \mathrm{C}$ (Figure 1). This study, to collect THI and RT data, was reviewed and approved by the Institutional Animal Care and Use Committee of China Agricultural University Beijing, China (permit number: DK996).

\section{THI vs RT during summer in Beijing}

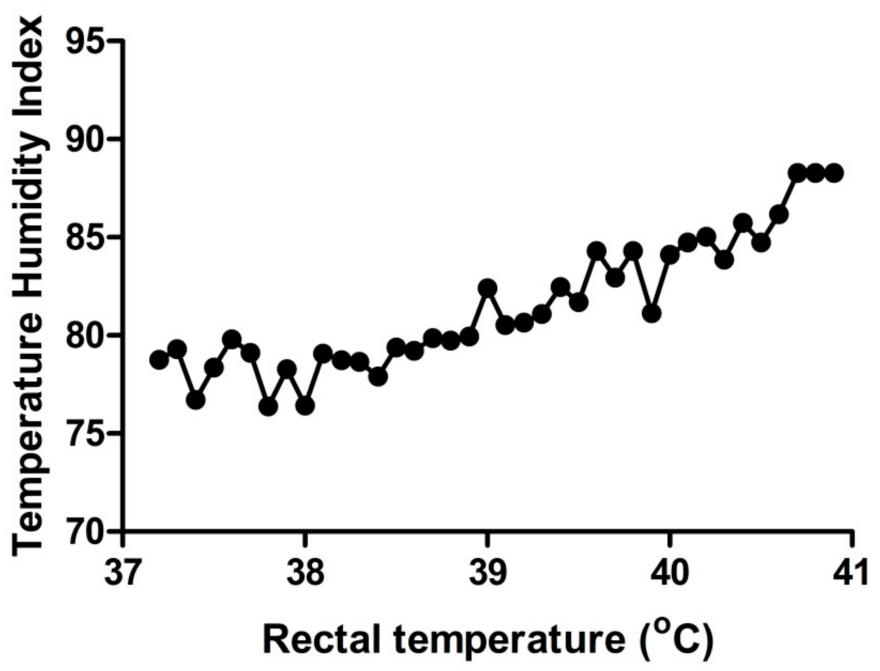

Figure 1. The temperature humidity index can affect rectal temperature (RT): Evaluation of change in RT with an increase in percent temperature humidity index (\% THI).

\section{Impact of Heat Stress on Cow Reproduction}

The effects of HS on dairy cow reproductive efficiency are well known, including increased incidence of anestrous in dairy cows and days open through disruption of the pregnancy rate $[27,28]$. HS in mammals is known to alter follicular dynamics [29], steroidogenic ability [30], GC function [31], and oocyte maturation [32], and may lead to reduced reproductive efficiency. In a tropical climate like in India, the sensitivity of dairy cattle to HS increases with an increase in milk production [33], which might be due to increased metabolic heat production with increased production levels in dairy animals. Likewise, HS results in maternal hyperthermia by increasing RT, which is responsible for impaired reproduction [34]. According to one large-scale retrospective study, the observed average rates of pregnancy to first artificial insemination (AI) and anestrous rates were respectively $44 \%$ and $27 \%$ for the cool period and 1.2\% and 12.9\% for warm [35]. This is seen in Figure 2, which demonstrates the depressive effect of summer heat on the conception rate of lactating cows artificially inseminated in the summer months over the last 18 years, as low as $27.7 \%$ compared to $42.6 \%$ during the cool winter months. Moreover, the slightly more severe conditions during the summers of 2010, 2012, and 2015, about $1.5^{\circ} \mathrm{C}$ above average summer air temperatures, further decreased conception by an additional $5 \%$ units (Figure 2) [36]. Therefore, the deteriorating effects of HS on reproductive efficiency during hot weather are vital in terms of the economic damage in addition to losses due to lower milk production. 


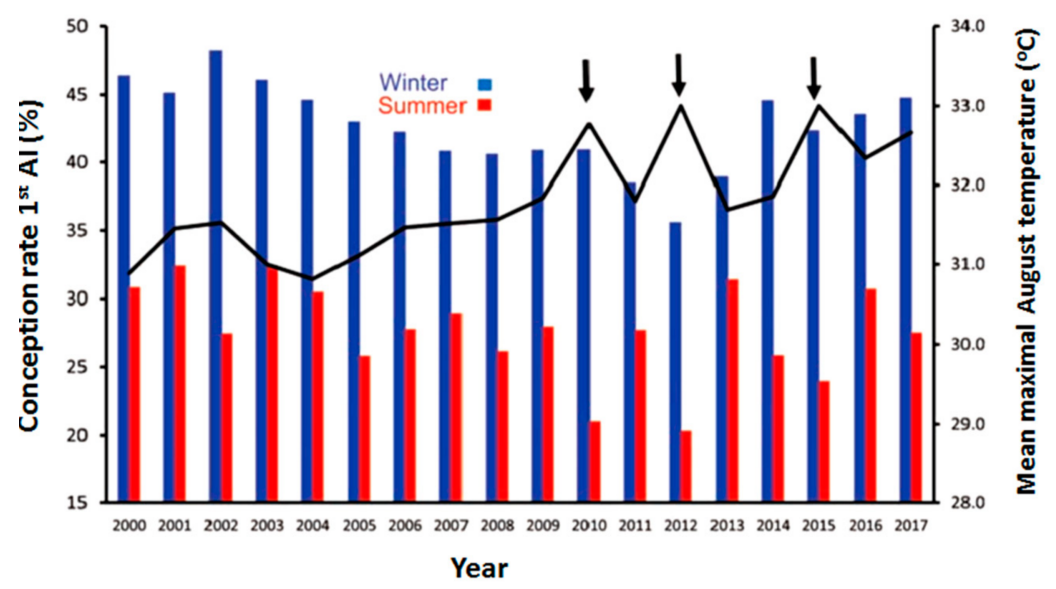

Figure 2. Conception rates of cows in dairy farms after the first insemination during the months of January-March (winter) or July-September (summer) of 2000-2017. The black curve represents the average environmental temperatures during August for each year. A noticeable decline in conception rates was observed during the intense conditions of summer in the years of 2010, 2012, and 2015.

\section{Hormonal Regulation and Estrous Behavior}

Since the release of gonadotrophin-releasing hormone $(\mathrm{GnRH})$ from the hypothalamus and the gonadotrophins, luteinizing hormone (LH), and follicle-stimulating hormone (FSH) from the anterior pituitary gland are the main factors which control ovarian function, some researchers have studied the impact of HS on the secretion of these hormones [37-40]. The observed effects of on LH concentrations in peripheral blood are inconsistent. Some studies reported unchanged concentrations [41], while others reported lower levels of steroids under gonadotropin stimulation following HS [40]. A decrease in LH pulse amplitude [42] and LH pulse frequency [43] has been reported with respect to the pattern of LH secretion in heat-stressed cows. Similarly, the effect of HS on the preovulatory LH surge is also controversial; a reduction in the endogenous LH surge by HS has been reported in heifers but not in cows. The reasons for these inconsistencies are unclear. These variations are suggested to be linked with preovulatory estradiol levels because the frequency of tonic LH pulses and preovulatory plasma LH surges caused by GnRH were decreased in cows with low plasma concentrations of estradiol (E2), but not in cows with high plasma concentrations of E2 [42]. The development of substandard corpus luteum (CL) with lower progesterone secretion might be due to the low LH surge. Additionally, impaired GnRH secretion in the summer can reduce cow fertility. Administration of GnRH for treating cystic ovaries and inducing ovulation appears to be a suitable approach for correcting the situation because during the estrous cycle, GnRH induces LH release, which makes the dominant ovarian follicles ovulate and enhances the conception rate in heat-stressed cows [44]. Since most of the studies found that HS is responsible for low levels of LH, we are led to infer that in summer, the dominant follicle grows in a low LH environment, resulting in reduced estradiol secretion from the dominant follicle, leading to poor expression of estrus and, hence, reduced fertility. Furthermore, during summer, plasma inhibin concentrations are lower in both heat-stressed cows [45] and cyclic buffaloes in India [46], possibly causing reduced folliculogenesis as a significant proportion of plasma inhibin was extracted from small- and medium-sized follicles.

Mammalian estrus also acts as a behavioral indicator, confirming if the female is bred near ovulation time. The observed core outcome in heat-stressed cows that up to $80 \%$ of estruses failed to be detected [47] due to a seasonal effect on estrous behavior [48]. Long-term exposure to a high ambient temperature compromised the conception rate by shortening the duration and reducing the intensity of estrus signs $[49,50]$. Moreover, hot weather during summer causes ovulation without showing signs of estrous [51]. Most likely, the lower level of blood E2 due to the disrupted steroidogenic potential of heat-stressed GCs is considered as the main cause of impaired heat detection [52]. Nonetheless, 
the cumulative pattern of impaired reproductive efficiency induced by heat stress [53] and is shown in Figure 3.

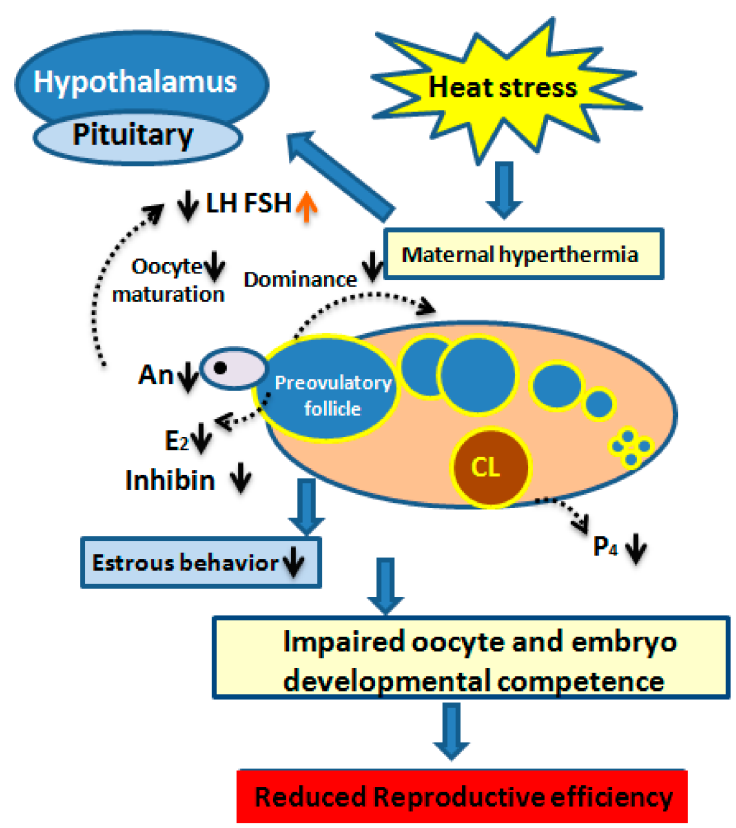

Figure 3. Diagram elucidating the interaction between the impact of seasonal heat stress and the hypothalamus-pituitary-ovarian axis and its mechanism of affecting dairy cow fertility. The lower luteinizing hormone ( $\mathrm{LH})$ surge is related to a decreased secretion of follicular estradiol(E2). Lower levels of androstenedione (An) and E2 levels are responsible for decreasing the dominance of preovulatory follicle and is related to poor estrous behavior. Likewise, impaired concentrations of follicle-stimulating hormone (FSH) and inhibin are related to the increased number of medium-sized follicles. Impaired competence of maturing oocyte and developing embryo is due to the disturbed nuclear and cytoplasmic maturation. Reduced reproductive efficiency in dairy cows is the ultimate outcome of heat stress.

\section{Impact of Heat Stress on Granulosa Cell Function}

GCs are somatic cells and are considered the most important ovarian cell type that surround, support, and nurture the developing oocyte physically and provide a suitable microenvironment for its maturation [54]. In the early phase of the primordial follicle, cells are incapable of producing steroidal hormones [54,55]. However, FSH stimulates GCs in the developmental stages before ovulation to convert androgens to estradiol via cytochrome P450 aromatase. After ovulation, GCs turn into progesterone-producing granulosa lutein cells. Progesterone (P4) plays a key role in maintaining pregnancy. One of the key roles of GCs is in the synthesis of two main reproductive steroid hormones in the ovary, i.e., E2 and P4 [56,57]. Estradiol plays an important role in the development of ovarian follicles, oocyte maturation, and endometrial proliferation. GCs have specific receptors for the gonadotropins FSH and LH [54], insulin-like growth factor (IGF) [58], and anti-Müllerian hormone $(\mathrm{AMH})[59,60]$. Any disturbance of GC quality and their proliferation capability may also have indirect effects on the development of the follicle and may disrupt oocyte maturation and, consequently, result in impaired embryo development with unsatisfactory pregnancy outcome [61].

HS is one of the compromising factors that affect the normal physiological functions of GCs by increasing intracellular accumulation of ROS, inducing apoptosis, and reducing the synthesis of E2 and P4 [52,62,63]. HS led to the induction of HSP genes in GCs [64-66]. Likewise, HSP induction was also reported in various cell/tissue types, such as leukocytes/lymphocytes [67-69], bovine endometrial tissue, bovine conceptuses [70,71], bovine MECs [72], and buffalo lymphocytes [73] due to HS. Moreover, it has been reported that HS causes an increase in HSPs in virtually all vertebrates, including mice [74,75], domestic goats [76], humans [77,78], juvenile hamadryas baboons [79], common carp [80], domestic 
chickens [81-83], and domestic turkey [84], thus supporting the idea that HSP70 can act as a reliable thermal stress biomarker. Upregulation of apoptotic genes (BCL2, BAX, CASP3) under HS could lead to a disruption of the potential of mitochondrion transmembrane, resulting in the release of cytochrome $c$ and cellular apoptosis [85]. However, the mitogen-activated protein kinase-mediated induction of HSP70 at high temperatures could play a crucial role in inhibiting Caspase- 3 and $B A X$ activation $[86,87]$. Therefore, we suggest that the induction of HSP70 might play a role in reducing apoptosis of GCs induced by HS.

HS results in intracellular ROS accumulation, causing oxidative stress [88] and apoptosis [89], which subsequently lead to a decline in fertility [31,90]. In response, the activation of fork head box O3 (FOXO3) and kelch-like ECH associated protein 1 (KEAP1) under HS protects cells from oxidative stress by upregulating antioxidant enzymes superoxide dismutase 2 (SOD2) and catalase (CAT) [60,91,92]. In Saccharomyces cerevisiae and quail, genes from the glutathione peroxidase family were also shown to be induced under HS $[93,94]$. Based on these facts, it is reasonable to suggest that the upregulation expression of SOD2 and CAT may inhibit ROS biosynthesis through the regulation of KEAP1 and FOXO3 in ovarian GCs.

Moreover, the regulation of genes related to steroidogenesis (E2 and P4), i.e., steroidogenic acute regulatory protein (STAR) and cytochrome P450, family 11, subfamily A, polypeptide 1 (CYP11A1) was affected by heat shock. Positive regulation of $\mathrm{P} 450$ aromatase family genes, such as CYP11A1, in the ovarian follicle promotes estrogen biosynthesis [95]. In addition, progesterone is also one of the fundamental steroid hormones for bovine estrous cycle regulation, and its biosynthesis is attributed to the increased expression of STAR and CYP11A1 [96-98]. Previously, it was reported that under HS, the mRNA expression of CYP11A1 and STAR decreased, but the P4 level had no significant $(p<0.05)$ difference between the control and heat treatment group [62]. Some studies reported an oversecretion of ovarian hormones in porcine ovarian GCs under high temperature [99]. Shown in Figure 4 is a brief overview of the mechanisms of regulating HS response which are related to GC function within the bovine ovary.

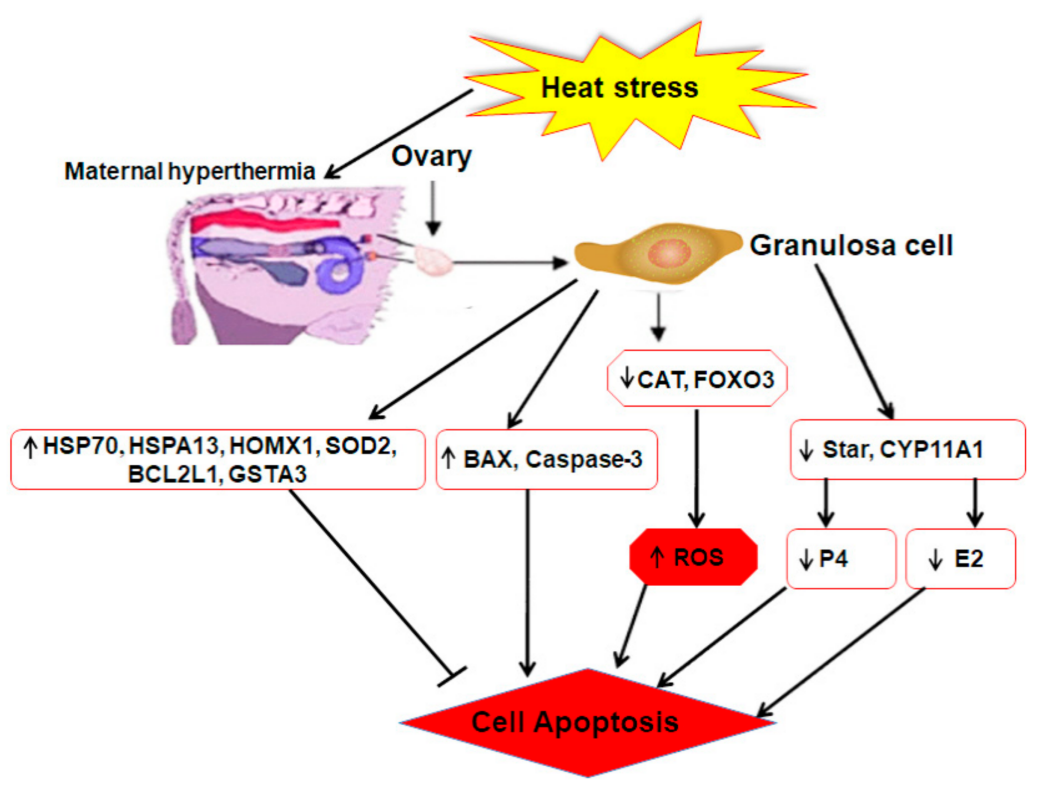

Figure 4. Mechanisms of regulating heat stress response related to follicular function within bovine ovary. Upregulated genes caspase-3, superoxide dismutase (SOD), $B C L-2$, and $B A X$, and heat shock proteins (HSPs) (HSP70, HSPA13, HMOX1) are involved in the regulating mechanism of bovine GCs via induced or inhibited cell apoptosis. Under heat stress, downregulated genes CAT and fork head box O3 (FOXO3) were involved in the production of reactive oxygen species (ROS). Likewise, downregulation of steroidogenic acute regulatory protein (STAR) and cytochrome P450, family 11, subfamily A, polypeptide 1 (CYP11A1) were involved in the secretion of E2 and progesterone (P4). Moreover, the decline of E2 and the enhancement of ROS might, in turn, enhance the possibility of GC apoptosis and follicle function. 


\section{Impact of Heat Stress on Ovarian Pool of Follicles and Oocyte Quality}

Folliculogenesis is the formation of a mature and/or Graafian follicle from a pool of primordial, non-growing follicles, and it is a long and highly dynamic process that occurs during the follicular phase of the estrous cycle of the female. A primordial follicle consists of an oocyte enclosed by a layer of flattened GCs. At birth, the ovary of the newborn heifer may approximately contain a total of 150,000 primordial follicles. This number decreases with the age of the cow, and after 15-20 years, it declines to 1000 follicles. Follicular development in cattle $[100,101]$ occurs in a wave-like pattern. The emergence of each follicular wave is stimulated by an FSH surge [102]. After emergence, follicles enter a common-growth phase, and the FSH surge begins to decline, reaching the lowest levels near the time of deviation [103]. This decline in FSH has been identified as a key component of the selection process because experimental administration of FSH during the common-growth phase of the wave in cattle [104] prevented deviation and allowed the development of multiple dominant follicles. A transient increase in circulating LH surrounding deviation has been reported in cattle $[105,106]$. Additionally, the expression of granulosa LH receptors has been reported to increase near deviation in the future dominant follicle $[107,108]$. The acquisition of LH receptors in the GCs of future dominant follicles might allow the LH to transiently increase and have a functional effect in the selection process. In this regard, LH is known to stimulate and increase estradiol concentrations in follicular fluid, which is involved in the continuing depression of FSH to concentrations lower than those required by the smaller follicles, thus facilitating the establishment of dominance [109]. The complete phase of bovine follicular development takes approximately 180 days [110]. Follicles at a primordial stage are considered to be insensitive to heat because no data are available that shows their sensitivity. Most of the studies focus on the impact of HS on the ovarian pool of follicles. The sensitivity and tolerance of the developing follicles and their enclosed oocytes to heat stress [53]. Follicular development from the primordial to the preovulatory stage involves three phases [111,112]. The first is the gonadotropin-independent phase that consists of the primary and secondary follicles, while the gonadotropin-dependent phase comprises early antral to preovulatory follicles. The sensitivity of follicles and developing oocytes increases from the primordial stage to the preovulatory stage $[113,114]$.

Oocyte development is extremely sensitive to high temperatures. During follicular growth, the developmental potential of the oocyte is gained in a stepwise pattern and, thus, the disruption in the follicular microenvironment and their function induced by heat stress may result in impaired oocyte competency. During the summer, oocytes collected from Holstein cows were delayed in the first two embryonic divisions [52,115]. A period of two to three consecutive estrous cycles may be needed for the recovery of an oocyte from summer heat damage and, further, to regain competency in the following autumn [116], suggesting a long-term consequence of HS on the ovarian pool of oocytes. This might be the reason that even during autumn (i.e., when there is no environmental thermal stress), the fertility of cows is compromised. It is notable that maternal hyperthermia results in the impairment of only a subpopulation of the ovarian follicles, rather than the entire follicular pool, as evidenced by the spontaneous restoration of the oocyte competence and pregnancy rate in the autumn and subsequent winter. Failure of oocyte maturation under HS happens in many ways. It disturbs the biosynthesis of steroid hormones, such as LH, that are involved in the regulating mechanisms of oocyte maturation [52]. In addition, it also induces oxidative stress because HS enhances the production of ROS and lowers the level of glutathione and as was found in the heat-stressed oocytes and embryos of mouse $[16,117,118]$. Oxidative stress is one of the most common factors that compromises normal cellular physiological functions, destroys the intracellular structure, and eventually leads to cell death. Thus, it harms oocyte maturation in both in vivo and in vitro environments. It was previously stated that $\mathrm{HS}\left(42^{\circ} \mathrm{C}\right)$ encourages apoptosis in surrounding cumulus cells and decreases the oocyte maturation rates during the germinal vesicle breakdown stage [119]. Furthermore, a significantly increased ratio of ROS/GSH was reported in the heat-stressed oocyte [118]. Similarly, HS can block the nuclear maturation of oocytes, leading to a decrease in polar body rate. For example, upon exposure to a temperature of $41{ }^{\circ} \mathrm{C}$, the maturation rate of bovine oocytes was significantly reduced [120]. Furthermore, HS can 
also disrupt the cytoskeletal structure of oocytes [121]. On the other hand, HS highly regulates the gene expression of HSP70, the apoptotic gene caspase-3, and other antioxidant-related genes (SOD1, $C A T$, and $C P X 4)$ in cumulus oophorus complex (COC). These changes in gene regulation imitate the self-defense mechanisms of COCs under HS. HSP70 is a multi-effect factor, maintaining stability of the intracellular environment and inhibiting cell apoptosis [122]. The expression of HSP70 can also protect cells from apoptosis by regulating Caspase-3 and cytochrome c [123]. Therefore, it could be inferred that a high level of HSP70 helps oocyte survive from HS through upregulation of the SPKH1, BCL-2, SOD1, CAT, and CPX4 and downregulation of $p 53$.

\section{Conclusions}

Heat stress affects the reproductive efficiency of dairy cattle in a variety of ways. Understanding of the cellular and molecular responses of oocyte and GCs in response to HS will be helpful in developing strategies for heat resistance in dairy cattle. The genes regulated by heat stress are potential heat resistance markers that can be targeted in dairy cattle.

Author Contributions: Conceptualization, A.K. and Y.W.; writing—original draft preparation, A.K. and M.Z.K.; writing-review and editing, S.U., I.M.K. and H.X.; visualization, H.Z. All authors have read and agreed to the published version of the manuscript.

Funding: We acknowledge financial support from the Modern Agro-industry Technology Research System (CARS-36); the Program for Changjiang Scholar and Innovation Research Team in University (IRT_15R62).

Conflicts of Interest: The authors declare no conflicts of interest. The funders had no role in study design, decision to publish, and preparation of the manuscript.

\section{References}

1. Hansen, P.J. Effects of heat stress on mammalian reproduction. Philos. Trans. R. Soc. B Biol. Sci. 2009, 364, 3341-3350. [CrossRef] [PubMed]

2. Torres-Júnior, J.R.d.S.; Pires, M.d.F.A.; de Sá, W.F.; Ferreira, A.d.M.; Viana, J.H.M.; Camargo, L.S.A.; Ramos, A.A.; Folhadella, I.M.; Polisseni, J.; de Freitas, C.; et al. Effect of maternal heat-stress on follicular growth and oocyte competence in Bos indicus cattle. Theriogenology 2008, 69, 155-166. [CrossRef]

3. Kobayashi, Y.; Wakamiya, K.; Kohka, M.; Yamamoto, Y.; Okuda, K. Summer heat stress affects prostaglandin synthesis in the bovine oviduct. Reproduction 2013, 146, 103-110. [CrossRef] [PubMed]

4. Shehab-El-Deen, M.A.M.M.; Leroy, J.L.M.R.; Fadel, M.S.; Saleh, S.Y.A.; Maes, D.; Van Soom, A. Biochemical changes in the follicular fluid of the dominant follicle of high producing dairy cows exposed to heat stress early post-partum. Anim. Reprod. Sci. 2010, 117, 189-200. [CrossRef] [PubMed]

5. Heldmaier, G.; Ortmann, S.; Elvert, R. Natural hypometabolism during hibernation and daily torpor in mammals. Respir. Physiol. Neurobiol. 2004, 141, 317-329. [CrossRef] [PubMed]

6. Pohl, C.R.; Richardson, D.W.; Hutchison, J.S.; Germak, J.A.; Knobil, E. Hypophysiotropic signal frequency and the functioning of the pituitary-ovarian system in the rhesus monkey. Endocrinology 1983, 112, 2076-2080. [CrossRef] [PubMed]

7. Campbell, B.K.; Dobson, H.; Scaramuzzi, R.J. Ovarian function in ewes made hypogonadal with GnRH antagonist and stimulated with FSH in the presence or absence of low amplitude LH pulses. J. Endocrinol. 1998, 156, 213-222. [CrossRef]

8. Voronina, E.; Lovasco, L.A.; Gyuris, A.; Baumgartner, R.A.; Parlow, A.F.; Freiman, R.N. Ovarian granulosa cell survival and proliferation requires the gonad-selective TFIID subunit TAF4b. Dev. Biol. 2007, 303, 715-726. [CrossRef]

9. Su, Y.Q.; Wu, X.; O’Brien, M.J.; Pendola, F.L.; Denegre, J.N.; Matzuk, M.M.; Eppig, J.J. Synergistic roles of BMP15 and GDF9 in the development and function of the oocyte-cumulus cell complex in mice: Genetic evidence for an oocyte-granulosa cell regulatory loop. Dev. Biol. 2004, 276, 64-73. [CrossRef]

10. Eppig, J.J. Oocyte control of ovarian follicular development and function in mammals. Reproduction 2001, 122, 829-838. [CrossRef] 
11. Da Silva-Buttkus, P.; Jayasooriya, G.S.; Mora, J.M.; Mobberley, M.; Ryder, T.A.; Baithun, M.; Stark, J.; Franks, S.; Hardy, K. Effect of cell shape and packing density on granulosa cell proliferation and formation of multiple layers during early follicle development in the ovary. J. Cell Sci. 2008, 121, 3890-3900. [CrossRef]

12. Sakatani, M.; Yamanaka, K.; Balboula, A.Z.; Takenouchi, N.; Takahashi, M. Heat stress during in vitro fertilization decreases fertilization success by disrupting anti-polyspermy systems of the oocytes. Mol. Reprod. Dev. 2015, 82, 36-47. [CrossRef]

13. Wegner, K.; Lambertz, C.; Das, G.; Reiner, G.; Gauly, M. Effects of temperature and temperature-humidity index on the reproductive performance of sows during summer months under a temperate climate. Anim. Sci.J. 2016, 87, 1334-1339. [CrossRef] [PubMed]

14. Hansen, P.J.; Aréchiga, C.F. Strategies for managing reproduction in the heat-stressed dairy cow. J. Anim. Sci. 1999, 77, 36-50. [CrossRef]

15. Sammad, A.; Umer, S.; Shi, R.; Zhu, H.; Zhao, X.; Wang, Y. Dairy cow reproduction under the influence of heat stress. J. Anim. Physiol. Anim. Nutr. (Berl.) 2019, 1-9. [CrossRef] [PubMed]

16. Matsuzuka, T.; Ozawa, M.; Nakamura, A.; Ushitani, A.; Hirabayashi, M.; Kanai, Y. Effects of heat stress on the redox status in the oviduct and early embryonic development in mice. J. Reprod. Dev. 2005, 51, 281-287. [CrossRef]

17. Li, L.; Wu, J.; Luo, M.; Sun, Y.; Wang, G. The effect of heat stress on gene expression, synthesis of steroids, and apoptosis in bovine granulosa cells. Cell Stress Chaperones 2016, 21, 467-475. [CrossRef] [PubMed]

18. Fujita, J. Cold shock response in mammalian cells. J. Mol. Microbiol. Biotechnol. 1999, 1, 243-255. [PubMed]

19. Collier, R.J.; Stiening, C.M.; Pollard, B.C.; Vanbaale, M.J.; Baumgard, L.H.; Gentry, P.C.; Coussens, P.M. Use of gene expression microarrays for evaluating environmental stress tolerance at the cellular level in cattle 1. J. Anim. Sci. 2014, 1-13. [CrossRef]

20. Page, T.J.; Sikder, D.; Yang, L.; Pluta, L.; Wolfinger, R.D.; Kodadek, T.; Thomas, R.S. Genome-wide analysis of human HSF1 signaling reveals a transcriptional program linked to cellular adaptation and survival. Mol. Biosyst. 2006, 2, 627-639. [CrossRef]

21. Lee, W.C.; Wen, H.C.; Chang, C.P.; Chen, M.Y.; Lin, M.T. Heat shock protein 72 overexpression protects against hyperthermia, circulatory shock, and cerebral ischemia during heatstroke. J. Appl. Physiol. 2006, 100, 2073-2082. [CrossRef]

22. Dikmen, S.; Hansen, P.J. Is the temperature-humidity index the best indicator of heat stress in lactating dairy cows in a subtropical environment? J. Dairy Sci. 2009, 92, 109-116. [CrossRef] [PubMed]

23. West, J.W. Effects of heat-stress on production in dairy cattle. J. Dairy Sci. 2003, 86, 2131-2144. [CrossRef]

24. Kadokawa, H.; Sakatani, M.; Hansen, P.J. Perspectives on improvement of reproduction in cattle during heat stress in a future Japan. Anim. Sci. J. 2012, 83, 439-445. [CrossRef] [PubMed]

25. Kadzere, C.T.; Murphy, M.R.; Silanikove, N.; Maltz, E. Heat stress in lactating dairy cows: A review. Livest. Prod. Sci. 2002, 77, 59-91. [CrossRef]

26. Mader, T.L.; Davis, M.S. Environmental factors influencing heat stress in feedlot cattle 1, 2. Glob. Environ. Chang. 2006, 84, 712-719.

27. Wolfenson, D.; Roth, Z.; Meidan, R. Impaired reproduction in heat-stressed cattle: Basic and applied aspects. Anim. Reprod. Sci. 2000, 60-61, 535-547. [CrossRef]

28. Oseni, S.; Misztal, I.; Tsuruta, S.; Rekaya, R. Seasonality of days open in US Holsteins. J. Dairy Sci. 2003, 86, 3718-3725. [CrossRef]

29. Ozawa, M.; Tabayashi, D.; Latief, T.A.; Shimizu, T.; Oshima, I.; Kanai, Y. Alterations in follicular dynamics and steroidogenic abilities induced by heat stress during follicular recruitment in goats. Reproduction 2005, 129, 621-630. [CrossRef]

30. Shimizu, T.; Oshima, I.; Ozawa, M.; Takahashi, S.; Tajima, A.; Shiota, M.; Miyazaki, H.; Kanai, Y. Heat stress diminishes gonadotropin receptor expression and enhances susceptibility to apoptosis of rat granulosa cells. Reproduction 2005, 129, 463-472. [CrossRef]

31. Fu, Y.; He, C.J.; Ji, P.Y.; Zhuo, Z.Y.; Tian, X.Z.; Wang, F.; Tan, D.X.; Liu, G.S. Effects of melatonin on the proliferation and apoptosis of sheep granulosa cells under thermal stress. Int. J. Mol. Sci. 2014, 15, 21090-21104. [CrossRef] [PubMed]

32. Mustafi, S.B.; Chakraborty, P.K.; Dey, R.S.; Raha, S. Heat stress upregulates chaperone heat shock protein 70 and antioxidant manganese superoxide dismutase through reactive oxygen species (ROS), p38MAPK, and Akt. Cell Stress Chaperones 2009, 14, 579-589. [CrossRef] [PubMed] 
33. Sunil Kumar, B.V.; Kumar, A.; Kataria, M. Effect of heat stress in tropical livestock and different strategies for its amelioration. J. Stress Physiol. Biochem. 2011, 7, 45-54.

34. Vale, W.G. Effects of environment on buffalo reproduction. Ital. J. Anim. Sci. 2007, 6, 130-142. [CrossRef]

35. López-Gatius, F. Is fertility declining in dairy cattle? A retrospective study in northeastern Spain. Theriogenology 2003, 60, 89-99. [CrossRef]

36. Wolfenson, D.; Roth, Z. Impact of heat stress on cow reproduction and fertility. Anim. Front. 2019, 9, 32-38. [CrossRef]

37. Wolfenson, D.; Lew, B.J.; Thatcher, W.W.; Graber, Y.; Meidan, R. Seasonal and acute heat stress effects on steroid production by dominant follicles in cows. Anim. Reprod. Sci. 1997, 47, 9-19. [CrossRef]

38. Roth, Z.; Meiden, R.; Braw-Tal, R.; Wolfenson, D. Immediate and delayed effects of heat stress on follicular development and its association with plasma FSH and inhibin concentration in cows. J. Reprod. Fertil. 2000, 120, 83-90. [CrossRef]

39. Kanai, Y.; Yagyu, N.; Shimizu, T. Hypogonadism in Heat Stressed Goats: Poor Responsiveness of the Ovary to the Pulsatile LH Stimulation Induced by Hourly Injections of a Small Dose of GnRH. J. Reprod. Dev. 1995, 41, 133-139. [CrossRef]

40. Bridges, P.J.; Brusie, M.A.; Fortune, J.E. Elevated temperature (heat stress) in vitro reduces androstenedione and estradiol and increases progesterone secretion by follicular cells from bovine dominant follicles. Domest. Anim. Endocrinol. 2005, 29, 508-522. [CrossRef]

41. Howell, J.L.; Fuquay, J.W.; Smith, A.E. Corpus Luteum Growth and Function in Lactating Holstein Cows During Spring and Summer. J. Dairy Sci. 1994, 77, 735-739. [CrossRef]

42. Gilad, E.; Meidan, R.; Berman, A.; Graber, Y.; Wolfenson, D. Effect of heat stress on tonic and GnRH-induced gonadotrophin secretion in relation to concentration of oestradiol in plasma of cyclic cows. J. Reprod. Fertil. 1993, 99, 315-321. [CrossRef] [PubMed]

43. Wise, M.E.; Armstrong, D.V.; Huber, J.T.; Hunter, R.; Wiersma, F. Hormonal Alterations in the Lactating Dairy Cow in Response to Thermal Stress. J. Dairy Sci. 1988, 71, 2480-2485. [CrossRef]

44. Chenault, J.R.; Kratzer, D.D.; Rzepkowski, R.A.; Goodwin, M.C. LH and FSH response of Holstein heifers to fertirelin acetate, gonadorelin and buserelin. Theriogenology 1990, 34, 81-98. [CrossRef]

45. Wolfenson, D.; Bartol, F.F.; Badinga, L.; Barros, C.M.; Marple, D.N.; Cummins, K.; Wolfe, D.; Lucy, M.C.; Spencer, T.E.; Thatcher, W.W. Secretion of PGF2 $\alpha$ and oxytocin during hyperthermia in cyclic and pregnant heifers. Theriogenology 1993, 39, 1129-1141. [CrossRef]

46. Palta, P.; Mondal, S.; Prakash, B.S.; Madan, M.L. Peripheral inhibin levels in relation to climatic variations and stage of estrous cycle in buffalo (bubalus bubalis). Theriogenology 1997, 47, 989-995. [CrossRef]

47. Thatcher, W.W.; Macmillan, K.L.; Hansen, P.J.; Drost, M. Concepts for regulation of corpus luteum function by the conceptus and ovarian follicles to improve fertility. Theriogenology 1989, 31, 149-164. [CrossRef]

48. Roelofs, J.; López-Gatius, F.; Hunter, R.H.F.; van Eerdenburg, F.J.C.M.; Hanzen, C. When is a cow in estrus? Clinical and practical aspects. Theriogenology 2010, 74, 327-344. [CrossRef]

49. López-Gatius, F.; Santolaria, P.; Mundet, I.; Yániz, J.L. Walking activity at estrus and subsequent fertility in dairy cows. Theriogenology 2005, 63, 1419-1429. [CrossRef]

50. Sakatani, M.; Balboula, A.Z.; Yamanaka, K.; Takahashi, M. Effect of summer heat environment on body temperature, estrous cycles and blood antioxidant levels in Japanese Black cow. Anim. Sci. J. 2012, 83, 394-402. [CrossRef]

51. López-Gatius, F.; Mirzaei, A.; Santolaria, P.; Bech-Sàbat, G.; Nogareda, C.; García-Ispierto, I.; Hanzen, C.; Yániz, J.L. Factors affecting the response to the specific treatment of several forms of clinical anestrus in high producing dairy cows. Theriogenology 2008, 69, 1095-1103. [CrossRef] [PubMed]

52. Roth, Z.; Meidan, R.; Shaham-Albalancy, A.; Braw-Tal, R.; Wolfenson, D. Delayed effect of heat stress on steroid production in medium-sized and preovulatory bovine follicles. Reproduction 2001, 121, 745-751. [CrossRef] [PubMed]

53. Roth, Z. Effect of Heat Stress on Reproduction in Dairy Cows: Insights into the Cellular and Molecular Responses of the Oocyte. Annu. Rev. Anim. Biosci. 2017, 5, 151-170. [CrossRef] [PubMed]

54. Edson, M.A.; Nagaraja, A.K.; Matzuk, M.M. The mammalian ovary from genesis to revelation. Endocr. Rev. 2009, 30, 624-712. [CrossRef]

55. Richards, J.S.; Midgley, A.R. Protein Hormone Action: A Key to Understanding Ovarian Follicular and Luteal Cell Development. Biol. Reprod. 1976, 14, 82-94. [CrossRef] 
56. Oktay, K.; Briggs, D.; Gosden, R.G. Ontogeny of follicle-stimulating hormone receptor gene expression in isolated human ovarian follicles. J. Clin. Endocrinol. Metab. 1997, 82, 3748-3751. [CrossRef]

57. Albertini, D.F.; Combelles, C.M.H.; Benecchi, E.; Carabatsos, M.J. Cellular basis for paracrine regulation of ovarian follicle development. Reproduction 2001, 121, 647-653. [CrossRef]

58. Senthilkumaran, B.; Yoshikuni, M.; Nagahama, Y. A shift in steroidogenesis occurring in ovarian follicles prior to oocyte maturation. Mol. Cell. Endocrinol. 2004, 215, 11-18. [CrossRef]

59. Adashi, E.Y. The IGF family and folliculogenesis. J. Reprod. Immunol. 1998, 39, 13-19. [CrossRef]

60. Umer, S.; Sammad, A.; Zou, H.; Khan, A.; Weldegebriall Sahlu, B.; Hao, H.; Zhao, X.; Wang, Y.; Zhao, S.; Zhu, H. Regulation of AMH, AMHR-II, and BMPs $(2,6)$ Genes of Bovine Granulosa Cells Treated with Exogenous FSH and Their Association with Protein Hormones. Genes. 2019, 10, 1038. [CrossRef]

61. Wu, K.C.; McDonald, P.R.; Liu, J.J.; Chaguturu, R.; Klaassen, C.D. Implementation of a High-Throughput Screen for Identifying Small Molecules to Activate the Keap1-Nrf2-ARE Pathway. PLoS ONE 2012, 7, 44686. [CrossRef] [PubMed]

62. Morgan, S.; Anderson, R.A.; Gourley, C.; Wallace, W.H.; Spears, N. How do chemotherapeutic agents damage the ovary? Hum. Reprod. Update 2012, 18, 525-535. [CrossRef] [PubMed]

63. Li, J.; Gao, H.; Tian, Z.; Wu, Y.; Wang, Y.; Fang, Y.; Lin, L.; Han, Y.; Wu, S.; Haq, I.U.; et al. Effects of chronic heat stress on granulosa cell apoptosis and follicular atresia in mouse ovary. J. Anim. Sci. Biotechnol. 2016, 7, 1-10. [CrossRef] [PubMed]

64. Liu, Z.Q.; Shen, M.; Wu, W.J.; Li, B.J.; Weng, Q.N.; Li, M.; Liu, H.L. Expression of PUMA in Follicular Granulosa Cells Regulated by FoxO1 Activation During Oxidative Stress. Reprod. Sci. 2015, 22, 696-705. [CrossRef] [PubMed]

65. Heads, R.J.; Yellon, D.M.; Latchman, D.S. Differential cytoprotection against heat stress or hypoxia following expression of specific stress protein genes in myogenic cells. J. Mol. Cell. Cardiol. 1995, 27, 1669-1678. [CrossRef]

66. Iwazawa, M.; Acosta, T.J. Effect of elevated temperatures on bovine corpus luteum function: Expression of heat-shock protein 70, cell viability and production of progesterone and prostaglandins by cultured luteal cells. Anim. Prod. Sci. 2014, 54, 285-291. [CrossRef]

67. Harada, T.; Koi, H.; Kubota, T.; Aso, T. Haem oxygenase augments porcine granulosa cell apoptosis in vitro. J. Endocrinol. 2004, 181, 191-205. [CrossRef]

68. Agnew, L.L.; Colditz, I.G. Development of a method of measuring cellular stress in cattle and sheep. Vet. Immunol. Immunopathol. 2008, 123, 197-204. [CrossRef]

69. Dangi, S.S.; Gupta, M.; Maurya, D.; Yadav, V.P.; Panda, R.P.; Singh, G.; Mohan, N.H.; Bhure, S.K.; Das, B.C.; Bag, S.; et al. Expression profile of HSP genes during different seasons in goats (Capra hircus). Trop. Anim. Health Prod. 2012, 44, 1905-1912. [CrossRef]

70. Guerriero, V.; Raynes, D.A. Synthesis of heat stress proteins in lymphocytes from livestock. J. Anim. Sci. 1990, 68, 2779-2783. [CrossRef]

71. Malayer, J.R.; Hansen, P.J.; Buhi, W.C. Effect of day of the oestrous cycle, side of the reproductive tract and heat shock on in-vitro protein secretion by bovine endometrium. J. Reprod. Fertil. 1988, 84, 567-578. [CrossRef] [PubMed]

72. Putney, D.J.; Malayer, J.R.; Gross, T.S.; Thatcher, W.W.; Hansen, P.J.; Drost, M. Heat Stress-Induced Alterations in the Synthesis and Secretion of Proteins and Prostaglandins by Cultured Bovine Conceptuses and Uterine Endometrium1. Biol. Reprod. 1988, 39, 717-728. [CrossRef] [PubMed]

73. Collier, R.J.; Dahl, G.E.; Vanbaale, M.J. Major advances associated with environmental effects on dairy cattle. J. Dairy Sci. 2006, 89, 1244-1253. [CrossRef]

74. Mishra, A.; Hooda, O.K.; Singh, G.; Meur, S.K. Influence of induced heat stress on HSP70 in buffalo lymphocytes. J. Anim. Physiol. Anim. Nutr. (Berl.) 2011, 95, 540-544. [CrossRef]

75. Beck, S.C.; Paidas, C.N.; Tan, H.; Yang, J.; De Maio, A. Depressed expression of the inducible form of HSP 70 (HSP 72) in brain and heart after in vivo heat shock. Am. J. Physiol.-Regul. Integr. Comp. Physiol. 1995, 269, 608-613. [CrossRef]

76. Albers, R.; Van Der Pijl, A.; Bol, M.; Seinen, W.; Pieters, R. Stress proteins (HSP) and chemical-induced autoimmunity. Toxicol. Appl. Pharmacol. 1996, 140, 70-76. [CrossRef] 
77. Meza-Herrera, C.A.; Martínez, L.; Aréchiga, C.; Bañuelos, R.; Rincón, R.M.; Urrutia, J.; Salinas, H.; Mellado, M. Circannual identification and quantification of constitutive heat shock proteins (HSP 70) in goats. J. Appl. Anim. Res. 2006, 29, 9-12. [CrossRef]

78. Hayashi, Y.; Tohnai, I.; Kaneda, T.; Kobayashi, T.; Ohtsuka, K. Translocation of hsp-70 and Protein Synthesis during Continuous Heating at Mild Temperatures in HeLa Cells. Radiat. Res. 1991, 125, 80. [CrossRef]

79. Kim, D.; Somji, S.; Garrett, S.H.; Sens, M.A.; Shukla, D.; Sens, D.A. Expression of hsp 27, hsp 60, hsc 70, and hsp 70 by immortalized human proximal tubule cells (HK-2) following exposure to heat shock, sodium arsenite, or cadmium chloride. J. Toxicol. Environ. Heal. Part A 2001, 63, 475-493. [CrossRef]

80. Dehbi, M.; Baturcam, E.; Eldali, A.; Ahmed, M.; Kwaasi, A.; Chishti, M.A.; Bouchama, A. Hsp-72, a candidate prognostic indicator of heatstroke. Cell Stress Chaperones 2010, 15, 593-603. [CrossRef]

81. Ferencz, Á.; Juhász, R.; Butnariu, M.; Deér, K.A.; Varga, I.S.; Nemcsók, J. Expression analysis of heat shock genes in the skin, spleen and blood of common carp (Cyprinus carpio) after cadmium exposure and hypothermia. Acta Biol. Hung. 2012, 63, 15-25. [CrossRef] [PubMed]

82. Givisiez, P.E.N.; Ferro, J.A.; Ferro, M.I.T.; Kronka, S.N.; Decuypere, E.; Macari, M. Hepatic concentration of heat shock protein $70 \mathrm{kD}$ (Hsp70) in broilers subjected to different thermal treatments. Br. Poult. Sci. 1999, 40, 292-296. [CrossRef] [PubMed]

83. Hernandes, R.; Ferro, J.A.; Gonzales, E.; Ferro, M.I.T.; Macari, M.; Bernal, F.E.M. Resistance to ascites syndrome, homoeothermic competence and levels of Hsp70 in the heart and lung of broilers. Rev. Bras. Zootec. 2002, 31, 1442-1450. [CrossRef]

84. Zulkifli, I.; Che Norma, M.T.; Israf, D.A.; Omar, A.R. The effect of early-age food restriction on heat shock protein 70 response in heat-stressed female broiler chickens. Br. Poult. Sci. 2002, 43, 141-145. [CrossRef] [PubMed]

85. Wang, S.; Edens, F.W. Stress-induced heat-shock protein synthesis in peripheral leukocytes of turkeys, Meleagris gallopavo. Comp. Biochem. Physiol. Part B Biochem. 1993, 106, 621-628. [CrossRef]

86. Mosser, D.D.; Caron, A.W.; Bourget, L.; Meriin, A.B.; Sherman, M.Y.; Morimoto, R.I.; Massie, B. The Chaperone Function of hsp70 Is Required for Protection against Stress-Induced Apoptosis. Mol. Cell. Biol. 2000, 20, 7146-7159. [CrossRef]

87. Stankiewicz, A.R.; Lachapelle, G.; Foo, C.P.Z.; Radicioni, S.M.; Mosser, D.D. Hsp70 inhibits heat-induced apoptosis upstream of mitochondria by preventing Bax translocation. J. Biol. Chem. 2005, 280, 38729-38739. [CrossRef]

88. Lee, J.M.; Lee, J.M.; Kim, K.R.; Im, H.; Kim, Y.H. Zinc preconditioning protects against neuronal apoptosis through the mitogen-activated protein kinase-mediated induction of heat shock protein 70. Biochem. Biophys. Res. Commun. 2015, 459, 220-226. [CrossRef]

89. Azad, M.A.K.; Kikusato, M.; Sudo, S.; Amo, T.; Toyomizu, M. Time course of ROS production in skeletal muscle mitochondria from chronic heat-exposed broiler chicken. Comp. Biochem. Physiol. Mol. Integr. Physiol. 2010, 157, 266-271. [CrossRef]

90. Gu, Z.T.; Li, L.; Wu, F.; Zhao, P.; Yang, H.; Liu, Y.S.; Geng, Y.; Zhao, M.; Su, L. Heat stress induced apoptosis is triggered by transcription-independent $\mathrm{p} 53, \mathrm{Ca}^{2+}$ dyshomeostasis and the subsequent Bax mitochondrial translocation. Sci. Rep. 2015, 5, 1-15. [CrossRef]

91. Guérin, P.; El Mouatassim, S.; Ménézo, Y. Oxidative stress and protection against reactive oxygen species in the pre-implantation embryo and its surroundings. Hum. Reprod. Update 2001, 7, 175-189. [CrossRef] [PubMed]

92. Alemu, T.W.; Pandey, H.O.; Wondim, D.S.; Neuhof, C.; Tholen, E.; Holker, M.; Schellander, K.; Tesfaye, D. Oxidative and endoplasmic reticulum stress defense mechanisms of bovine granulosa cells exposed to heat stress. Theriogenology 2018, 110, 130-141. [CrossRef] [PubMed]

93. Alcendor, R.R.; Gao, S.; Zhai, P.; Zablocki, D.; Holle, E.; Yu, X.; Tian, B.; Wagner, T.; Vatner, S.F.; Sadoshima, J. Sirt1 Regulates Aging and Resistance to Oxidative Stress in the Heart. Circ. Res. 2007, 100, 1512-1521. [CrossRef]

94. Dilantha Fernando, W.G.; Ramarathnama, R.; Akkanas, S.K.; Savchuk, S.C. Identification and use of potential bacterial organic antifungal volatiles in biocontrol. Soil Biol. Biochem. 2005, 37, 955-964.

95. Del Vesco, A.P.; Gasparino, E. Production of reactive oxygen species, gene expression, and enzymatic activity in quail subjected to acute heat stress. J. Anim. Sci. 2013, 91, 582-587. [CrossRef] [PubMed] 
96. Mendelson, C.R.; Jiang, B.; Shelton, J.M.; Richardson, J.A.; Hinshelwood, M.M. Transcriptional regulation of aromatase in placenta and ovary. J. Steroid Biochem. Mol. Biol. 2005, 95, 25-33. [CrossRef]

97. Mosa, A.; Neunzig, J.; Gerber, A.; Zapp, J.; Hannemann, F.; Pilak, P.; Bernhardt, R. 2 $\beta$ - and 16 $\beta$-hydroxylase activity of CYP11A1 and direct stimulatory effect of estrogens on pregnenolone formation. J. Steroid Biochem. Mol. Biol. 2015, 150,1-10. [CrossRef]

98. Zhang, J.Y.; Wu, Y.; Zhao, S.; Liu, Z.X.; Zeng, S.M.; Zhang, G.X. Lysosomes are involved in induction of steroidogenic acute regulatory protein (StAR) gene expression and progesterone synthesis through low-density lipoprotein in cultured bovine granulosa cells. Theriogenology 2015, 84, 811-817. [CrossRef]

99. Rekawiecki, R.; Nowik, M.; Kotwica, J. Stimulatory effect of LH, PGE2 and progesterone on StAR protein, cytochrome $\mathrm{P} 450$ cholesterol side chain cleavage and $3 \beta$ hydroxysteroid dehydrogenase gene expression in bovine luteal cells. Prostaglandins Other Lipid Mediat. 2005, 78, 169-184. [CrossRef]

100. Sirotkin, A.V.; Bauer, M. Heat shock proteins in porcine ovary: Synthesis, accumulation and regulation by stress and hormones. Cell Stress Chaperones 2011, 16, 379-387. [CrossRef]

101. Pierson, R.A.; Ginther, O.J. Ultrasonic imaging of the ovaries and uterus in cattle. Theriogenology 1988, 29, 21-37. [CrossRef]

102. Fortune, J.E.; Sirois, J. Ovarian Follicular Dynamics during the Estrous Cycle in Heifers Monitored by Real-Time Ultrasonography. Biol. Reprod. 1988, 39, 308-317.

103. Adams, G.P.; Matteri, R.L.; Kastelic, J.P.; Ko, J.C.H.; Ginther, O.J. Association between surges of follicle-stimulating hormone and the emergence of follicular waves in heifers. J. Reprod. Fertil. 1992, 94, 177-188. [CrossRef] [PubMed]

104. Ginther, O.J.; Bergfelt, D.R.; Kulick, L.J.; Kot, K. Pulsatility of systemic FSH and LH concentrations during follicular-wave development in cattle. Theriogenology 1998, 50, 507-519. [CrossRef]

105. Mihm, M.; Good, T.E.M.; Ireland, J.L.H.; Ireland, J.J.; Knight, P.G.; Roche, J.F. Decline in Serum Follicle-Stimulating Hormone Concentrations Alters Key Intrafollicular Growth Factors Involved in Selection of the Dominant Follicle in Heifers1. Biol. Reprod. 1997, 57, 1328-1337. [CrossRef]

106. Kulick, L.J.; Kot, K.; Wiltbank, M.C.; Ginther, O.J. Follicular and hormonal dynamics during the first follicular wave in heifers. Theriogenology 1999, 52, 913-921. [CrossRef]

107. Kulick, L.J.; Bergfelt, D.R.; Kot, K.; Ginther, O.J. Follicle Selection in Cattle: Follicle Deviation and Codominance Within Sequential Waves1. Biol. Reprod. 2001, 65, 839-846. [CrossRef]

108. Beg, M.A.; Bergfelt, D.R.; Kot, K.; Wiltbank, M.C.; Ginther, O.J. Follicular-Fluid Factors and Granulosa-Cell Gene Expression Associated with Follicle Deviation in Cattle1. Biol. Reprod. 2001, 64, 432-441. [CrossRef]

109. Xu, Z.; Allen Garverick, H.; Smith, G.W.; Smith, M.F.; Hamilton, S.A.; Youngquist, R.S. Expression of Follicle-Stimulating Hormone and Luteinizing Hormone Receptor Messenger Ribonucleic Acids in Bovine Follicles during the First Follicular Wave1. Biol. Reprod. 1995, 53, 951-957. [CrossRef]

110. Ginther, O.J.; Bergfelt, D.R.; Kulick, L.J.; Kot, K. Selection of the Dominant Follicle in Cattle: Role of Estradiol1. Biol. Reprod. 2000, 63, 383-389. [CrossRef]

111. Lussier, J.G.; Matton, P.; Dufour, J.J. Growth rates of follicles in the ovary of the cow. J. Reprod. Fertil. 1987, 81, 301-307. [CrossRef] [PubMed]

112. Orisaka, M.; Tajima, K.; Tsang, B.K.; Kotsuji, F. Oocyte-granulosa-theca cell interactions during preantral follicular development. J. Ovarian Res. 2009, 2, 1-7. [CrossRef] [PubMed]

113. Campbell, B.K. The endocrine and local control of ovarian follicle development in the ewe. Anim. Reprod. 2009, 6, 159-171.

114. Nilsson, E.E.; Skinner, M.K. Progesterone regulation of primordial follicle assembly in bovine fetal ovaries. Mol. Cell. Endocrinol. 2009, 313, 9-16. [CrossRef]

115. Kim, J.Y. Control of ovarian primordial follicle activation. Clin. Exp. Reprod. Med. 2012, 39, 10-14. [CrossRef]

116. Gendelman, M.; Roth, Z. Incorporation of Coenzyme Q10 into Bovine Oocytes Improves Mitochondrial Features and Alleviates Effects of Summer Thermal Stress on Developmental Competence. Biol. Reprod. 2012, 87, 115. [CrossRef]

117. Roth, Z.; Arav, A.; Bor, A.; Zeron, Y.; Braw-Tal, R.; Wolfenson, D. Improvement of quality of oocytes collected in the autumn by enhanced removal of impaired follicles from previously heat-stressed cows. Reproduction 2001, 122, 737-744. [CrossRef]

118. Ozawa, M.; Hirabayashi, M.; Kanai, Y. Developmental competence and oxidative state of mouse zygotes heat-stressed maternally or in vitro. Reproduction 2002, 124, 683-689. [CrossRef] 
119. Wang, J.Z.; Sui, H.S.; Miao, D.Q.; Liu, N.; Zhou, P.; Ge, L.; Tan, J.H. Effects of heat stress during in vitro maturation on cytoplasmic versus nuclear components of mouse oocytes. Reproduction 2009, 137, 181-189. [CrossRef]

120. Yuan, Y.; Hao, Z.D.; Liu, J.; Wu, Y.; Yang, L.; Liu, G.S.; Tian, J.H.; Zhu, S.E.; Zeng, S.M. Heat shock at the germinal vesicle breakdown stage induces apoptosis in surrounding cumulus cells and reduces maturation rates of porcine oocytes in vitro. Theriogenology 2008, 70, 168-178. [CrossRef]

121. Payton, R.R.; Romar, R.; Coy, P.; Saxton, A.M.; Lawrence, J.L.; Edwards, J.L. Susceptibility of Bovine Germinal Vesicle-Stage Oocytes from Antral Follicles to Direct Effects of Heat Stress In Vitro1. Biol. Reprod. 2004, 71, 1303-1308. [CrossRef] [PubMed]

122. Pablos, M.I.; Agapito, M.T.; Gutierrez, R.; Recio, J.M.; Reiter, R.J.; Barlow-Walden, L.; Acuña-Castroviejo, D.; Menendez-Pelaez, A. Melatonin stimulates the activity of the detoxifying enzyme glutathione peroxidase in several tissues of chicks. J. Pineal Res. 1995, 19, 111-115. [CrossRef] [PubMed]

123. Brodsky, J.; Chiosis, G. Hsp70 Molecular Chaperones: Emerging Roles in Human Disease and Identification of Small Molecule Modulators. Curr. Top. Med. Chem. 2006, 6, 1215-1225. [CrossRef] [PubMed]

(C) 2020 by the authors. Licensee MDPI, Basel, Switzerland. This article is an open access article distributed under the terms and conditions of the Creative Commons Attribution (CC BY) license (http://creativecommons.org/licenses/by/4.0/). 